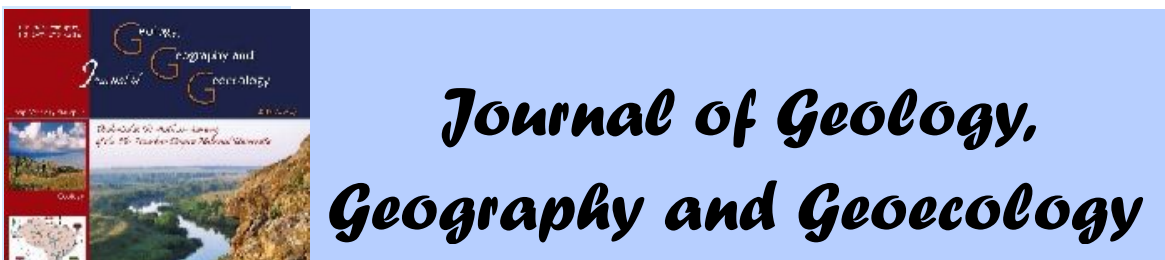

Journal home page: geology-dnu-dp.ua

\title{
Recreational skiing in the formation of local settlement systems of Prykarpattya region
}

\author{
I. Rusanova, Y.Onufriv, A.Ignatyuk \\ Department of Urban Planning and Design, Institute of Architecture, Lviv Polytechnic National University; \\ Bandery Street, 12, room 323, 79013, Lviv, Ukraine, e-mail: yarynaonufriv@gmail.com
}

Received 08.07.2018;

Received in revised form 27.07.2018;

Accepted 01.08.2018

the functioning and development of such systems and is simultaneously an integral part
of them. The settlement systems in the mountainous areas of Ivano-Frankivsk region, which are based on recreational skiing are highlighted and investigated, in particular they are: the Kosiv system, the Yaremche-Vorokhta system (consisting of two subsystems of the Yaremche and Vorokhta -Yablunytsya), the Verkhovyna system and autonomous centers of recreational skiing in the villages Vyshkiv and Guta . Their detailed profile in demographic terms, including migration processes; natural resource possibilities; socioeconomic potential and interaction with recreational skiing is outlined. The methodological principles of the spatial structure formation of local settlement systems are based on the following states of the system approach: - the main territorial-planning elements of the systems are defined: skiing complexes (one large enterprise or a group of enterprises) with a ski area and a development zone; center of the system, which is a tourist center with services, production and transport; settlements with rural territories and enterprises of the agro-industrial complex; valuable landscape (national parks, nature reserves); focal points of tourist destinations;- functional and spatial associations of ski recreation facilities with settlements, recreational, natural and nature-protected areas, and engineering-transport infrastructure are established;- the approximate boundaries of systems are determined on the basis of spatial, functional and labour relations, types of their territorial-spatial structure, distances between settlements accepted within the radius of one hour transport accessibility.Planning types, directions and trends of development and spatial transformation of local settlement systems with recreational skiing are identified. The role and significance of local settlement systems with recreational skiing as an urban planning object is demonstrated within the general system of recreational zoning.

Key words: local settlement systems, recreational skiing, spatial structure of resettlement

\section{ірськолижн рекре ція у формув нні лок льних систем розселення рик рп ття}

. . ус нов , . . нуфрів, . . гн тюК

федр містобудув ння, нститут рхітектури, ціон льний університет « ввівськ політехнік »; вул. . ндери, 12, к.323, 79013, ввів, кр їн ;е-mail: yarynaonufriv@gmail.com

нот ція. ормув ння лок льних систем розселення, розглянутих н прикл ді гірських р йонів рик рп ття ( в ноp нківськ обл сть, кр їн ) відбув ється н основі скл дного комплексу чинників, серед яких гірськолижн рекре ція відігр є провідну роль у функціонув нні і розвитку т ких систем т одноч сно є їх скл довою. иділено і досліджено системи розселення в гірській ч стині в но- р нківської обл сті, які розвив ються н б зі гірськолижної рекре ції, с ме: осівську, ремч нсько- орохтянську (до скл ду якої входять дві підсистеми ремч нськ і орохтянсько- блуницьк ), ерховинську т втономні осередки гірськолижної рекре ції в с. ишків і в с. ут. од н їх дет льн х р ктеристик 3 демогр фічною ситу цією, в тому числі мігр ційними процес ми; природно-ресурсними можливостями; соці льноекономічним потенці лом т вз ємодією з гірськолижною рекре цією. озроблені методичні з с ди формув ння територі льно-просторової структури лок льних систем розселення н основі положень системного підходу. изн чено типи пл нув льних структур, н прямки і тенденції розвитку й просторової тр нсформ ції систем розселення . ок з но роль і зн чення систем розселення з гірськолижною рекре цією як об'єкт містобудівного проектув ння у з г льній системі рекре ційного p йонув ння.

лючові слов : лок льн систем розселення, гірськолижн рекре ція, територі льн структур розселення 
Introduction. Nowadays recreational skiing is one of the most popular types of winter recreation. Its popularity is attested by the construction of new ski resorts and other objects connected to this form of recreation in mountains, and their spread throughout the world.

Ski resorts or sets of recreational skiing objects function in settlement systems of different hierarchical ranks - regional, district and local. The closest connections between recreational skiing objects exist within a limited local area because of the common use of recreational potential of the territory, infrastructure, workforce and socioeconomic base of the settlements, which are subordinated to self-government bodies and territorial communities.

The formation of local settlement systems is considered on the example of Ivano-Frankivsk region (Ukraine), which consists of six mountainous areas. These areas differ in the amount of recreational skiing objects of different capacity, natural resource potential, socio-economic development of the settlements and infrastructure.

Recreational skiing as a leading branch of economic activity of closely located and interconnected settlements (local settlement systems) creates the base for the production activity of the population, increases the chances of introducing other additional sectors of tourist servicing, thereby exercising the mutual influence of mountain recreation and settlement systems.

Investigation of recreational territories is highlighted in numerous works of researchers covering a wide range of problems in the spheres of geography, economics, social ecology, urban planning, etc. In Ukraine, a thorough basis of settlement systems research was laid out by the urbanist researchers: Y. Bilokon, I. Fomin, M. Kushnirenko, M. Dyomin, M. Habrel, I. Rusanova and others. The formation of territorial recreational systems was investigated by the urbanists T. Panchenko, V. Shulyk, V. Vladimirov, and also by geographers $\mathrm{O}$. Preobragenskyi, V. Dgaman, A, Dotsenko, P. Maslyak, M. Palamarchuk, F. Mazur, O. Beidyk and others. Regional problems of the Ukrainian Carpathians, in particular landscape and urban problems, resource base, historical and cultural potential, were explored by T. Panchenko, M. Habrel, Y. Taras, H. Petryshyn, G. Shulga and others. The influence of various types of recreation, and in particular recreational skiing, on the activation of the development of settlements of the Carpathian region is discussed by scientists: M. Greta, T. Kostrzewa-Zielinska, J. Mirek, A. Ilieş, D. Ilieş, O. Dehoorne.

In recent years on the initiative of the European Union and with the participation of Ukraine, mountainous areas development programmes and strategies have been developed and implemented. One of them, "EU Macro-regional strategy for the Carpathian region" (Szuba, 2017) determines the modern directions of development of this region, which mainly concerns higher-ranking systems. This work has not paid attention to the formation of settlement systems at the local level with the specificity of solving problems and taking into account the features of the territorial planning on the basis of recreational skiing.

The aim of this study is to develop criteria and mechanisms for the formation of local settlement systems on the basis of recreational skiing in the mountainous areas of the Carpathians (on the example of Ivano-Frankivsk region) and to determine the principles for improving their territorial organisation and development.

Material and methods. The research is based on the analysis of the research publications and project materials in relation to this topic, as well as on field surveys of 13 ski resorts in the mountain districts of Ivano-Frankivsk region.During field surveys the capacity of ski resorts, the quantity and quality of their services, their role and significance beyond and within the boundaries of the state, region and district were determined (Onufriv, 2017).

During the study of individual settlements, statistical data, empirical methods and content analysis of the theory and practice of recreation formation in resettlement systems were used. In the survey of ski recreation objects and settlements within the studied territory, cartographic materials were used.

The basic method of research is system analysis and principles of system formation, where at the lowest level - the local system, interconnected settlements are considered as a single organism with territorial-production, cultural and economic, transport, tourist and recreational links.

Results and discussion. On the Ukrainian territory of the Carpathians, the Prykarpattya region is distinguished as a separate region with the predominant function of mountain recreation. Part of IvanoFrankivsk region is fully part of Prykarpattya, and this is almost $50 \%$ of the area of the region with mountain ranges: the Eastern Beskydy, Gorgany, Pokutski mountains, and separately - the ranges of Chornogora with the highest peak of Hoverla. Establishment of settlements in these areas is traced to the 16th-17th centuries, and the population consists mainly of Ukrainian-highlanders - Hutsuls with their rich culture, customs, architecture, which is reflected in the specifics of these mountainous regions.

Since ancient times, natural conditions have made this region a tourist pilgrimage area, which later became the place of recreational skiing on a 
large scale- the main direction of economic activity and socio-economic development of local settlements.

The recreational attractiveness of this area lies not only in the natural-landscape conditions and picturesque landscapes, but also in its geographical po-sition on the border with Romania, through which the tourist routes to Bulgaria, Serbia, Montenegro, and Greece are laid.

A group of recreational facilities (or one object) create their own zone of influence associated with the zoning of the recreational area. In this case, the concept of "recreational territory" is treated as a component of the land fund with a system of interconnected natural, natural-social and social components (Beidyk, 2001). The methodology of taxonomic zoning of recreational territories is considered by T. Panchenko (2009) at the level of the region, district, tourist area, taking into account the area of the recreational territories. Specialists use different criteria for zoning of territories, reflecting the spatial dispersion of recreational resources . According to V. Shulyk (2007), a recreational area is a type of functional-branch zoning, which is based on recreational orientation. G. Shulga (2015) emphasizes the role of landscapes in the zoning of a territory. The proposed methodology of "landscape-spatial pools", which are territories limited by watersheds of different order, is attached to urban systems at the level of the region, zone, district, area.

The existing method of regionalisation of recreational territories does not give a clear definition of the size and subordination of taxonomic units of these territories, their connection with the settlement systems. A more objective definition exists for territorial-recreational systems in the territory of a certain taxonomic rank of the complex of recreational establishments based on the use of resources of this territory, spatially and territorially interconnected ones (Maslyak, 2008). Thus, the system concept of recreation, which includes the territorial integrity of the system with interconnected subsystems (natural resources, objects of historical and urban planning and cultural heritage, engineering infrastructure, service and management), is included in this definition; hierarchy (region, zone, district, territorial recreation complex). The territorial recreational complex can be regarded as a low link in such a hierarchy, represented by an object or a group of recreational facilities operating on a particular territory with natural and socioeconomic characteristics. Objects of territorial recreational complexes provide a significant set of variants of territorial and economic system formation at different hierarchical levels. At the lower hierarchical level, recreational facilities (ski resorts) are located on a limited local area, establish close links with neighbouring settlements, providing not only recreational services, but also performing territorial functions through the sharing of natural, labour and other resources.

Ski complexes, as a rule, are combined with other types of recreation (from extreme to passive recreation), and aimed at their year-round operation regardless of the season. Mountain recreation spreads its influence on the surrounding settlements with their cultural-historical and ethnic characteristics, which provide a material base and service, and promote the attractiveness and multiplicity of mountain resorts. Due to such interconnections local settlements are formed, in which mountain recreation becomes the organizer of socioeconomic development of settlements themselves and in the system.

Methodological aspects of the research on settlement systems that operate on a separate territory include the following factors: natural resources, socio-economic potential, demographic situation, migration processes in the formation of settlement potential (Dgaman, 2003). The general factors of formation affecting local systems of resettlement with recreational skiing are manifested in the identification of natural and recreational resources that contribute to the directions of the related types of recreation within such systems, the socio-economic and demographic situation of settlements for recreation services and infrastructure development. These same factors generally determine the spatial structure of systems.

The methodological principles of the formation of the spatial structure of local systems are based on the following states of the system approach:

- the main territorial-planning elements of the systems are defined: skiing complexes (one large enterprise or a group of enterprises) with a ski area and a development zone; center of the system, which is a tourist center with services, production and transport; settlements with rural territories and enterprises of the agro-industrial complex; valuable landscape (national parks, nature reserves); focal points of tourist destinations.

- functional and spatial associations of recreational skiing facilities with settlements, recreational, natural and nature-protected areas, and engineering-transport infrastructure are established.

- the approximate boundaries of systems are determined on the basis of spatial, functional and labour relations, types of their territorial-spatial structure, distances between settlements accepted within the radius of one hour transport accessibility.

Local settlement systems are not internally closed, but exist in the system of external connec- 
tions, which are found not only in the flows of recreation, but also in the influence of the foreign economic situation of the state, region, and district.

The internal factors of the formation of systems determine the type of the system, the boundaries of its localisation, which depend on the nature and parameters of the system-forming elements (recreational institutions, their concentration and territorial combination), socio-economic and demographic conditions of settlements, and communication infrastructure.

Systems with recreational skiing are considered as those where the set of services is different from other recreational territories. In some of them, recreational skiing dominates other industries, while in others it is an important but not the major function.

Unlike areas in the plains, the processes of living in mountain settlements are greatly complicated due to the smaller amount of agricultural land, the small sphere of application of labour, poor accessibility of public services, etc. Prykarpattya is a densely populated and weakly urbanised region with a specific weight of urban population of $42.9 \%$. The density of the village settlement network in the mountainous area is much smaller than in the lowlands, and at the same time the average population of a mountain village (1300 people / $\mathrm{km} 2)$ is greater than that of the villages in the plains (946 people / km2) (Dotsenko, 2007).

The peculiarity of living conditions in mountainous areas is acknowledged in the State Law of Ukraine "On the Status of Mountainous Settlements" (Verkhovna Rada of Ukraine, 2005), which provides some privileges to mountain settlements, which are clearly insufficient for their stable development. The functioning of mountain settlements and, in particular, sparsely populated settlements, can be achieved by linking them to more developed district centers, small towns or urban-type settlements, which ensure their development as ski resorts. This goal also corresponds to the unification of territorial communities, which is taking place in Ukraine today, creating local resettlement systems. On the basis of territorial proximityof settlements, their close interrelationships, common use of natural and material resources, common touristic infrastructure in the mountainous areas of IvanoFrankivsk region, the following local settlement systems based on recreational skiing are singled out: the Kosiv system, the Yaremche-Vorokhta system (consisting of two subsystems of the Yaremche and Vorokhta -Yablunytsya), the Verkhovyna system and autonomous centers of ski recreation in the Vyshkiv area and in Guta village.
Placement of settlements relative to the main highways and secondary roads, their status, size, as well as the role in the system (center, sub-centers, specialised centers, settlements) determine the type of their planning structure (Fig. 1).

The analysis of local settlement systems in the mountainous areas of Ivano-Frankivsk region, based on the indicators of the demographic situation, the number and size of settlements with the presence in their composition of the ski resort facilities, shown in Table 1, revealed differences in their characteristics. Thus, the number of interconnected settlements (and hence rural communities) is combined into set-tlement systems of different sizes that do not correlate with the general density and percentage of urban and rural population $(0.67 \%)$ than the average indicator $(0.57 \%)$ in the region. This characteristic is supplemented by other factors: natural resources, urban conditions, labour potential, transport accessibility and a role of mountain recreation in a group of settlements. All these factors determine the specifics of each of the systems.

The Kosiv system (Fig. 2 A) is located in the foothills and lowlands of the Pokutsko-Bukovynian Carpathians, and has a linear-polycentric structure with a center in Kosiv, which lies on the highway of regional significance, which unites Verkhovyna, Vorokhta, Yaremche. This settlement system is distinguished by a rather high percentage of urban population and large populations of settlements. In the Kosiv area, there are three ski complexes that are weakly interconnected. In the town Kosiv and urban village Kuty most service facilities are centered. The largest settlement Pistyn, with a population of more than 4 thousand inhabitants, is located at the intersection of highways with a branch in Sheshory, has medical facilities and archeological remains. This system includes the national park "Hutsulshchyna", sanctuaries and protected tracts, and the settlements themselves form strands of resettlement along the roads. The multifunctionality of the system recreation, which is operated yearround, gives all grounds to consider it promising with high development potential.

The Yaremche-Vorokhta settlement system (Fig. 2 D) is divided into 2 subsystems. One of them consists of the city of the regional significance Yaremche and the historical settlements Mykulychyn and Tatariv, which form a linear structure on the highway of international significance. The center of this system in Yaremche is the oldest tourist center of the Carpathian region. The multioccupancy of this resort is complemented by a ski resort with medium difficulty trails. 


\begin{tabular}{|c|c|c|}
\hline $\begin{array}{l}\text { The name of } \\
\text { settlcment systcm } \\
\text { with ski recreation }\end{array}$ & 'The scherne of planning struelure & $\begin{array}{l}\text { The type of planning } \\
\text { structurc }\end{array}$ \\
\hline Kasiv system & & $\begin{array}{c}\text { linear- } \\
\text { polycentric }\end{array}$ \\
\hline $\begin{array}{c}\text { Yaremche- } \\
\text { vorokluta system }\end{array}$ & & $\begin{array}{c}\text { linear- } \\
\text { branehed }\end{array}$ \\
\hline $\begin{array}{l}\text { verkhovyna } \\
\text { system }\end{array}$ & & linearly dispersedl \\
\hline Vyshkiv system & & autonomous \\
\hline $\begin{array}{l}\text { Sulutvyn system } \\
\text { (Gula village with } \\
\text { ski resort) }\end{array}$ & & lincar \\
\hline
\end{tabular}

Fig. 1: Types of planning structures of local settlement systems with ski recreation: 1) - international highways; 2) - regional highways; 3) - roads of local importance; 4) - settlements with ski recreation; 5) - settlements (source: Iryna Rusanova, Iaryna Onufriv).

Tab. 1. Characteristics of local settlement systems of Prykarpattya (by the demographic situation and the presence of ski recreation facilities). Source: Main Department of Statistics in Ivano-Frankivsk Region, Ukraine (2017)

\begin{tabular}{|c|c|c|c|c|c|c|c|}
\hline \multicolumn{2}{|c|}{ Local settlement systems } & Kosiv & $\begin{array}{c}\text { Yaremche- } \\
\text { Vorochta (1- } \\
\text { subsystem with } \\
\text { the center in } \\
\text { Yaremche } \\
\end{array}$ & $\begin{array}{l}\text { Yaremche- } \\
\text { Vorochta }(2- \\
\text { subsystem with } \\
\text { the center in } \\
\text { Vorochta } \\
\end{array}$ & Verchovyna & Vyshkiv & Solotvyn \\
\hline \multirow{3}{*}{ Number of } & towns & 1 & 1 & - & - & - & - \\
\hline & $\begin{array}{c}\text { urban } \\
\text { villages }\end{array}$ & 1 & - & 1 & 1 & - & 1 \\
\hline & villages & 12 & 3 & 3 & 11 & 3 & 6 \\
\hline \multicolumn{2}{|c|}{ The system center } & Kosiv & Yaremche & Vorokhta & Verkhovyna & Vyshkiv & Solotvyno \\
\hline \multirow{4}{*}{$\begin{array}{l}\text { Number of } \\
\text { population }\end{array}$} & total & 37651 & 17147 & 7182 & 20675 & 2001 & 14522 \\
\hline & center & 8280 & 8168 & 4263 & 5872 & 651 & 3891 \\
\hline & urban, \% & 44 & 48 & 47 & 28 & - & 28 \\
\hline & rural, \% & 56 & 52 & 53 & 72 & 100 & 72 \\
\hline \multirow{2}{*}{$\begin{array}{c}\text { Population } \\
\text { density } \\
\left(\text { people } / \mathbf{k m}^{2}\right)\end{array}$} & total & 200.63 & 332.60 & 258.20 & 35.40 & 12 & 130 \\
\hline & center & 727.00 & 658.00 & 441.40 & 104.00 & 12.61 & 206.00 \\
\hline \multicolumn{2}{|c|}{$\begin{array}{c}\text { Ski recreation objects loca- } \\
\text { tion }\end{array}$} & $\begin{array}{l}\text { Kosiv, } \\
\text { Sheshory, } \\
\text { Tyudiv }\end{array}$ & Yaremche & $\begin{array}{l}\text { Vorochta, Yablu- } \\
\text { nytsya, Polyanyt- } \\
\text { sya (Bukovel) }\end{array}$ & $\begin{array}{l}\text { Verchovyna, } \\
\text { Iltsi }\end{array}$ & Vyshkiv & Guta \\
\hline \multicolumn{2}{|c|}{$\begin{array}{c}\text { Capacity of ski resort } \\
\text { (people/day) }\end{array}$} & up to 450 & $450-1200$ & $150-20000$ & $450-1200$ & $150-450$ & 150 \\
\hline
\end{tabular}


Located near Mykulychyn village with a population of about 5 thousand people, it has developed as a climatic resort. Tatariv village within the Carpathian National Nature Park on the banks of the Prut River can be considered as the most promising mountain resort due to the rich natural resources and geographical location on the highway leading to the largest ski resort Bukovel, village Yablunitsa and the urban village Vorokhta, forming a second subsystem with the center in Vorokhta near Yablunitsky Pass. The economic basis of the formation of this system, in addition to the multifunctional ski resort with tourist facilities, sports schools, health and recreational facilities, is
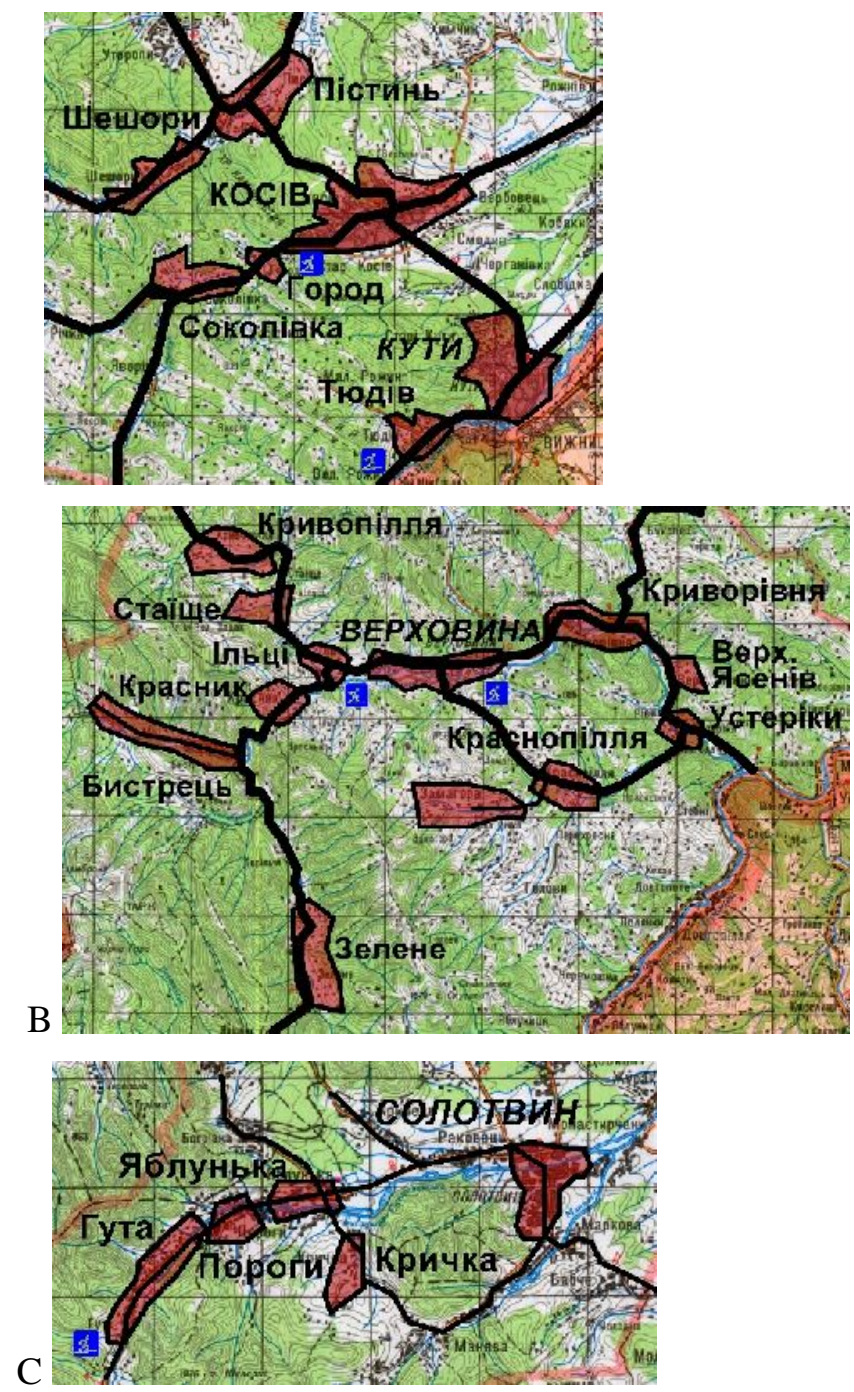

Fig.2: Local settlement systemswith ski recreation: A - Kosiv system; B - Verkhovyna system; C - Solotvyn system ; D Yaremche-Vorokhta system; E - Vyshkiv system(source: Iryna Rusanova, Iaryna Onufriv).

The Verkhovyna settlement system (Fig. 2 B) is characterised by a low population density, located in a mountainous area with the highest peaks of the Eastern Carpathians. This resulted in a linearly dispersed planning structure stretching livestock and plant cultivation, and industrial production on the basis of woodworking. This settlement system is an example of how recreational skiing with large scale skiing complexes contributed to the multiplicity of these settlement systems. Spa complexes, summer recreation by the water, quad bike rides and cycling complement the attractiveness of these complexes in the summer. The development in these areas of year-round recreational skiing complexes has led to the development of once remote peripheral settlements with the involvement of local residents in service recreation facilities, thereby providing them with work.
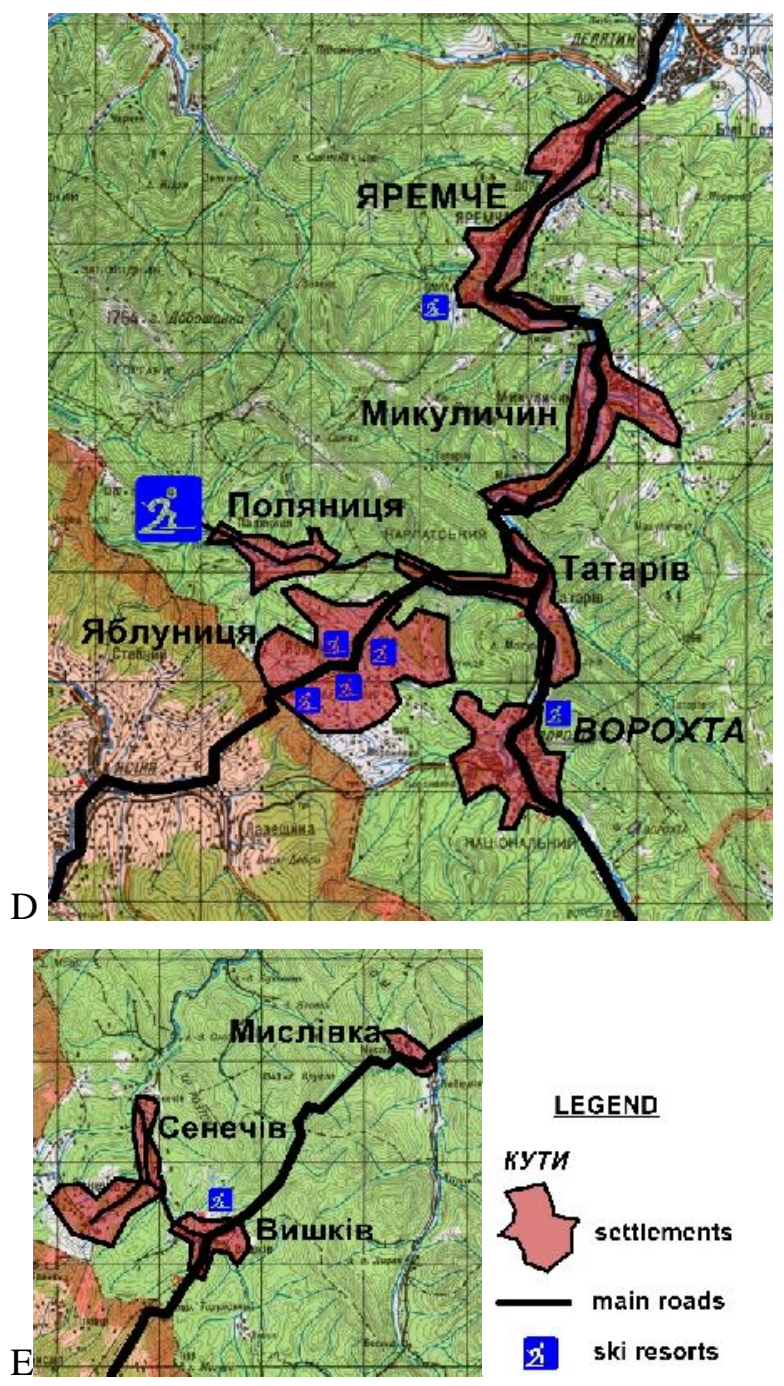

along the highway of regional significance with the center in the urban village Verkhovyna (until 1962 - it was called Zhabye) with the branching of a group of settlements along the Black Cheremosh River and in the south-easterly direction. Small ski 
resorts are concentrated in Verkhovyna and Iltsi, and such villages as Kryvorivnya (ethnographic and cognitive tourism), Kryvopillya, Bystrets, Zamagora are specialised centers of hiking tourism, Dzembronja - the center of rural and extreme tourism (Kryvoruchko, Korol, Ignatyuk, 2007). The multifunctionality of recreation contributed to the development of light and food industries in the settlements. Land resources, unfavourable for arable land, led to the development of livestock and logging.

The Vyshkiv settlement system (Fig. 2 E) includes the autonomous group of settlements in the mountainous area of the Dolynsky district - the village of Vyshkiv and Myslivka on the highway Lviv-Khust and the village Senechiv near the village Vishkiv. This is a sparsely populated area with the lowest population density in the region. However, the rich natural conditions, the location along the tourist routes along the road to Lake Synevir, Vyshkivsky and the Torunsky Pass have created a tourist center here with hotels, camps, ski infrastructure in Vishkiv and Myslivka. The recreational potential of this area is far from exhausted, which makes it possible to create new multidisciplinary ski resorts here.

Recreational skiing in Guta village, which is a part of the Solotvyn settlement system (Fig. 2 C), is not dominant. The settlements are mainly concentrated in the valley of the Bistrica river, where the population is mostly occupied in agriculture and forestry, which is the economic basis for the development of this system. Guta village is considered to be the residence of elite recreation, here a small ski complex "Sinegora" works, as well as the beginning of tourist hiking trails in the mountain range of Gorgany .

The results of the analysis of existing settlement systems showed their irregularity in size, number and density of population, natural and urban conditions, infrastructure, the degree of recreational potential development, socio-economic base. According to these indicators, the most developed systems are the Yaremche-Vorokhta, Kosiv and Verkhovina systems.

Determination of trends in the further development of settlement systems should be based on factors that reflect the specifics of mountain areas:

- natural conditions (mountain ranges, reservoirs, forests, national parks and nature reserves);

recreational and tourist resources (availability and diversity of recreation, its capacity and attractiveness, conditions for all types of tourism);
- ecological (climate, lack of sources of air pollution, etc.);

- urban planning (number and size of settlements, transport infrastructure, the presence of links);

- demographic (population density, age and gender structure, migration processes, etc.);

- economic (recreational sphere, local production base, folk crafts).

As an obstacle to the development of the settlement network, the external factors inherent to the mountainous areas are: difficult living conditions at a distance to the centers with public services; deficit of agricultural land; low employment rate. The specificity of mountain territories is reflected in the "Development Strategy of the Ivano-Frankivsk Region 2020" (IvanoFrankivsk Regional Administration, 2014), which focuses on the social needs of the population and the economic benefits of the territories. With regard to local settlement systems, this means subordination to local interests and those internal factors that promote the development of territorial communities. The local settlement systems themselves are becoming areas of a communitybased administrative-territorial entities network formation.

Currently, within the framework of local settlement systems, the consolidation of territorial communities aimed at coherence of socio-economic and environmental measures, which will promote the sustainable development of systems, is being implemented. The association of villages with each other, as well as with urban settlements to solve common problems can be considered as an essential mechanism for the promotion of local systems to a qualitatively new level. The effect of such a mechanism can be seen on the example of Yaremche district in the developed strategy of the Yaremche-Vorokhta system development with the most important center of ski recreation.

On the example of the considered settlement systems it is possible to determine their future spatial development, having different forms of manifestation, defined as follows:

- Functional specialisation of each settlement system while preserving the leading role of the center of the system (Yaremche-Verkhovyna system: Mykulychyn, Tatariv, Polyanitsa).

- Territorial association of a group of settlements with the purpose of creating a specialised center-node (Verkhovyna, Kosiv system).

- Creation of a chain of settlements by integrating small settlements with a concentration of service functions in the center (Vyshkiv system).

Factors and principles of settlement systems formation, considered on the example of mountain- 
ous areas of Ukrainian Carpathians, can be applied to other regions of the Carpathian Mountains. These settlement systems are based on new criteria in the conditions of dynamic economic entities. The peculiarity of the considered systems is the active inclusion in the process of their development of recreational skiing, which is associated with the creation of a single natural-economic complex and at present is a critical condition for their functioning in the long term perspective.

Conclusions. Based on the above-mentioned material, it can be argued that local settlement systems are the main form of resettlement in the mountainous regions of the Carpathians. The principles of the formation of such systems on the basis of recreational skiing are considered only as a fragment of scientific knowledge on this problem, which allows a connection to be established between recreational skiing and settlement systems.

The placement of objects of recreational skiing in settlement systems is depicted in the design of schemes of local level. Within the spatial planning, the boundaries of settlement systems, the main and secondary axes of settlement systems development, as well as territories of different functional purposes are determined.

Thus, local settlement systems become a separate object of territorial planning at a lower level, where urgent problems are identified, priority to their solutions is given, and objects for investments are set.

In planning local settlement systems the opportunity is provided to make more informed decisions unlike the master plans that are currently being developed for settlements without considering them as elements of settlement systems and without taking into account systemic links, in particular, with objects of recreation.

Thus, local settlement systems as a multidisciplinary object of urban and spatial planning allow for a more in-depth study of the socio-economic, urban and natural basis of the settlement network at a lower level associated with the recreational skiing of the Carpathians in the framework of the overall strategy for the development of this macro-region.

\section{References}

Beydyk, O., 2001. Rekreatsiino-turystychni resursy Ukrainy. Metodolohiia i metodyka analizu, terminolohiia, raionuvannia [Recreational and tourist resources of Ukraine. Methodology and methods of analysis, terminology, zoning]. Kyiv, Kyiv University Publishing House (In Ukrainian).

Dgaman, V., 2003. Rehionalni systemy rozselennia: demohrafichni aspekty[Regional settlement systems: demographic aspects]. Chernivtsi, Ruta (In Ukrainian)..
Dotsenko, A., 2007. Sotsialno-ekonomichni problemy rozselennia i zainiatosti naselennia hustozaselenoho slabourbanizovanoho rehionu (na prykladi Ivano-Frankivskoi oblasti)[Socio-economic problems of resettlement and employment of the population of a densely populated weakly urbanised region (on example of Ivano-Frankivsk region)]. Retrieved from: http://ekhsuir.kspu.edu/bitstream/123456789/521 7/1/ \%20.\%20 оценко.pdf

Greta, M. andKostrzewa-Zielinska, T., 2011.Turystykaelementemaktywizacjigospodarcz ejregionówperyferyjnych - funkcjonowanieEuroregionuBeskidy[Tourism as an element of economic activation of peripheral regions functioning of the Beskidy Euroregion]. Zeszyty naukowe Uniwersytetu Szczecińskiego, 690(79) "Sport i recreacja. Szansa rozwoju regionu", Szczecin, Wydawnictwo Naukowe Uniwersytetu Szczecińskiego, 35-50.

Ilieş, A., Dehoorne, O., Ilieş, D.C.,2012. The crossborder territorial system in the RomanianUkrainian Carpathian area. Elements, mechanisms and structures generating premises for an integrated cross-border territorial system with tourist function. Carpathian Journal of Earth and Environmental Sciences, 7(1), 27 - 38 (In Ukrainian)..

Ivano-Frankivsk Regional Administration, 2014. Stratehiia rozvytku Ivano-Frankivskoi Oblasti na period do 2020 r. [Development Strategy of the IvanoFrankivsk Region 2020]. Retrieved from: http://www.if.gov.ua/files/SP_IF_oblast_4.pdf

Kryvoruchko, Y., Korol, Y., Ignatyk, A., 2007. Planuvalna orhanizatsiia turystychno-rekreatsiinoi struktury Verkhovynskoho raionu IvanoFrankivskoi oblasti[Planning organisation of tourist and recreational structure of Verkhovyna district of Ivano-Frankivsk region]. Scientific Journal of Lviv Polytechnic National University, 585, 65-70 (In Ukrainian)..

Main Department of Statistics in Ivano-Frankivsk Region, 2017. Statistical Yearbook of the IvanoFrankivsk Region in 2016. Ivano-Frankivsk.

Maslyak, T., 2008. Metodolohichni zasady rekreatsiinoi heohrafii. Terytorialni rekreatsiini systemy[Methodological principles of recreational geography. Territorial recreational systems]. In: Recreational geography, Chapter 4, Kyiv, Znannya (In Ukrainian)..

Mirek, J., 2011. Sport i rekreacja jako czynnik podnoszenia atrakcyjności gmin uzdrowiskowych na przykładzie Krynicy-Zdroju [Sport and recreation as a factor in increasing attractiveness of health resort communes on the example of KrynicaZdrój]. Zeszyty naukowe Uniwersytetu Szczecińskiego 690(79) "Sport i recreacja. Szansa rozwoju regionu", Szczecin, Wydawnictwo Naukowe Uniwersytetu Szczecińskiego, 303-318.

Onufriv, I., 2017. Kompozytsiini osnovy landshaftnoprostorovoi orhanizatsii hirskolyzhnykh kompleksiv (na prykladi Ukrainskykh Karpat)[Compositional foundations of ski resorts' 
landscape and spatial organisation (on example of the Ukrainian Carpathian Mountains]. PhD thesis. Lviv, Lviv Polytechnic National University (In Ukrainian)..

Panchenko, T., 2009. Turystychne seredovyshche: architektura, pryroda, infrastruktura [Touristic environ-ment: architecture, nature, infrastructure]. Kyiv, Logos (In Ukrainian)..

Rusanova, I., 2015. Formuvannia funktsionalnoplanuvalnoi struktury monotsentrychnykh miskykh ahlomeratsii 60-80 rokach XX stolittia (na prykladi Lvivskoi ahlomeratsii) [Formation of the functional and planning structure of monocentric urban agglomerations of the 60-80s of the 20th century (on the example of the Lviv agglomera-tion)] Lviv, Publishing house "Rastr-7" (In Ukrainian)..

Shulha, G., 2015. Metodyka modelyrovanyia planyrovochnoi orhanyzatsyy terrytoryi system rekreatsyy v Ukraynskykh Karpatakh [Methodology of modeling of planning organisation of territories of recreation systems in the Ukrainian Carpathians].
Science and Education, a New Dimension, Natural and Technical Sciences, 3(5), Issue 41, 8790(In Russian).

Shulyk, V., 2007. Pro rekreatsiine rayonuvannya terytorii Ukrainy [About recreational zoning of the territory of Ukraine]. Komunalnoye chozyaistvo gorodov, 76, 431 - 442 (In Ukrainian)..

Szuba, G., 2017. EU Macro-regional strategy for the Carpathian region. Ministry of the Environment, Poland, Modra. Retrieved from: http://www.carpathianconvention.org/tl_files/carp athiancon/Downloads/03\%20Meetings\%20and\%20EEv ent/Implementation\%20Committee/CCIC_Modra \%202017/documents/MRS\%20for\%20CarpaCarp a\%20Region\%20presentation.pdf

Verkhovna Rada of Ukraine, 2005. State Law of Ukraine: Pro status hirskykh naselenykh punktiv $\mathrm{v}$ Ukraini [About the status of mountain settlements in Ukraine]. Retrieved from: http://zakon2.rada.gov.ua/laws/show/56/95-вp (In Ukrainian). 